\title{
THE IMPLEMENTATION OF ENGLISH-MEDIUM INSTRUCTION IN UKRAINIAN HIGHER EDUCATION
}

\section{Olena Shcherbakova ${ }^{1}$ Svitlana Nikiforchuk ${ }^{2}$}

DOI: https://doi.org/10.30525/978-9934-26-069-8-14

Abstract. The purpose of the paper is to research, summarize and present the question of implementation of Content and Language Integrated Learning (CLIL) in the higher educational establishments of Ukraine. It is considered one of the most widespread and promising methods of teaching foreign languages. The effectiveness of the methodology is recognized in the European Union, and in some European countries CLIL goes to the level of the state educational program. The definition of CLIL, its goal, advantages and disadvantages are studied in the following paper. The obvious goal of CLIL is to provide students with a high level of foreign language proficiency in familiar conditions to a foreign environment, using the language as a means of subject studies and communication, one of the threads of CLIL is integrated language learning in professional activities, thus the article reflects the differences of CLIL from the other methods. The principles of studying the subject and language during the implementation of CLIL methodology in the process of foreign language education are presented by the authors. The use of CLIL methodology in different countries made it possible to determine its advantages, as well as certain problems of its implementation in the educational process. The question of the introduction of this methodology in higher educational establishments of Ukraine still remains open. The analysis of the methodology in the context of the chosen discipline, which is perceived as a practical course of learning a foreign language, is especially important for the research. Also the main objectives of CLIL methodology are distinguished in the given paper. The example of implementing CLIL methodology in practical

\footnotetext{
${ }^{1}$ Candidate of Pedagogical Sciences,

Assistant Lecturer at Department of English Language and Literature,

V.O. Sukhomlynskyi Mykolaiv National University, Ukraine

${ }^{2}$ Lecturer at Department of English Language and Literature,

V.O. Sukhomlynskyi Mykolaiv National University, Ukraine
} 
lessons is introduced in the paper and advantages and disadvantages of using this methodology in higher educational establishments of Ukraine are described. The effectiveness of CLIL methodology is ensured by conducting lessons in modern forms of interaction between the teacher and the student, with the use of innovative educational technologies, and allows students to simultaneously study both the language and the professional subject. The conclusions are made on the basis of detailed research of CLIL implementation in European and Ukrainian universities.

\section{Introduction}

Today, educational technologies are developing very rapidly - the market abandons with a wide variety of learning foreign languages methods offers. The question of methodology that is to be used in training becomes relevant. It is worth noting that at the end of the XX century methods of teaching foreign languages underwent great changes. Previously, all priorities were given to mechanical mastering of vocabulary, reading, translation and grammar, and the tasks were all repetitious. Now language learning has become more functional.

A large number of specialists in the fields of science, business, culture, technology, and many other areas of human activity began to pay attention to the language as a means of communication in the professional environment. The greatest value for them is a real communication with foreigners. In this regard, the vector of teaching a foreign language shifted from abstract and theoretical to applied, and became more functional.

European integration of Ukraine becomes agent for activating the process of mastering foreign languages and improving its quality, so Ukrainian researchers consider the latest world teaching methods in order to implement them in higher educational establishments of Ukraine.

Foreign language teaching (FL) through the content of special disciplines (content based second language instruction), meaningful integration in learning (CLIL - Content and Language Integrated Learning) and foreign-language immersion are the leading and most effective threads of optimization and intensification of students' mastery of a foreign language for professional purposes. They are widely used in universities of developed countries of the world. Unfortunately, FL teachers are not yet sufficiently aware of the essence of these three related approaches, which prevents their 
effective implementation for professional communication in the Ukrainian universities.

Presently, the most common and forward-looking methods of teaching foreign languages adopted in the European Union are CLIL and CALL, as the analysis of recent publications in this field shows $[5 ; 7 ; 8]$.

CALL is foreign languages teaching using a wide range of computer software tools for all available forms of foreign language teaching [8]. Taking into account that CALL is not considered an independent method of teaching foreign languages but is distinguished by many specialists only as one of the technical means of intensification and improvement of classroom and independent work [8], so we will take a closer look at CLIL methodology, which in some European countries, for example Finland, goes to the level of the state educational program.

The term CLIL (Content and Language Integrated Learning) was introduced by the researcher David Marsh in 1994 to identify the methodology of teaching comprehensive subjects in foreign languages. In Ukrainian, the abbreviation CLIL stands for subject-language integrated learning (or by L.G. Movchan: contextual-language integrated learning [3, p. 217]). That is, CLIL, according to Kochenkova O.M., is a content and language integrated learning that allows students to form linguistic and communicative competencies in a foreign language in the same educational context in which comprehensive knowledge and skills are formed and developed [2].

CLIL is considered one of the most widespread and promising methods of teaching foreign languages. The effectiveness of the methodology is recognized in the European Union, and in some European countries CLIL goes to the level of the state educational program.

Scientist Tarnopolsky O.B. considers CLIL as a related term in regards to the concept of teaching language through the content of specialization, optimization and intensification of students' mastering of FL for professional purposes [5]. The accumulated experience in integrated foreign language teaching by foreign scientists (March D., Malers A., Wolfe D. and others) shows that students studying with the help this method have the opportunity to fully immerse themselves in the natural language environment. Scientists also note that work on various topics allows to study specific terms, certain language structures - this contributes to replenishing the student's vocabulary with professional subject terminology and prepares him for further study 
and application of knowledge and skills gained [9]. The closest analogues of the above-mentioned methodology can be considered the Canadian practice of FL teaching through immersion, or American foreign language teaching programmes with a reliance on the subject content (content-based instruction) [2].

Currently, a large number of scientific publications justify the need to implement CLIL in higher educational establishments of Ukraine $[2 ; 3 ; 4 ; 5]$. But most publications focus on the organization of the educational process, provide recommendations on the selection of educational material for practical classes or independent work of students in comprehensive subjects. To implement CLIL methodology in the curriculum, it is necessary to carefully study the different models of integrated learning and find out the conditions for its successful realization.

\section{CLIL methodology}

For the last 20-30 years, the study of a foreign language by integrating it into the whole learning process, namely: teaching comprehensive subjects in a foreign language, has gained popularity. This approach makes the language not the purpose of learning, but a means, and develops the student's orientation and communication skills.

Integration of this kind satisfies the requests of students who are interested primarily in the applied aspect of a foreign language. In this context, the most interesting is the technique called CLIL (Content and Language Integrated Learning). It is a method of learning in which some of the subjects are taught in foreign languages. Thus, teaching students in their native and foreign languages becomes holistic.

The author of this methodical approach is David Marsh. In his article «The relevance and potential of content and language integrated learning (CLIL) for achieving MT+2 in Europe», the researcher admits that content and language integrated learning can be attributed to any educational context focused on two subjects, in which an additional language, that is, not the main language in which the whole course of study is conducted, is used as a means in teaching non-language subjects. The author emphasizes that the principle allows to study two languages simultaneously. The implementation of this method is carried out in different ways depending on the age and location of students [10]. 
The obvious goal of CLIL is to provide students with a high level of foreign language proficiency in familiar conditions to a foreign environment, using the language as a means of subject studies and communication, without forcing them to translate materials from their native language into a foreign language.

The second purpose of this method is the intercultural aspect. In addition to learning a foreign language, CLIL students will also learn the cultural peculiarities of the language and countries through the use of authentic materials.

The CLIL methodology is noted as innovative and progressive. It has a dual orientation: professional and linguistic. It is important that the study of the subject is carried out not only in a foreign language, but through it and with its help.

One of the threads of CLIL is integrated language learning in professional activities. The thread assumes that the students already have a profession in any field, and are studying in order to increase their communication skills in a foreign environment.

The following CLIL differences can be distinguished from other methods:

1. Knowledge of the language becomes not the purpose of study, but the means of studying professional subjects.

2. The language is integrated into a wider professional context.

3. The motivation for learning a language increases because students need knowledge and skills in their professional subjects. With the help of motivation, the quality of education also increases.

4. Language learning and improvement takes place naturally - in the process of professional communication. Students immediately practice their skills in the conditions in which they will use them in a foreign environment.

5. CLIL is part of continuous education.

6. Communicative language proficiency and knowledge of specific professional vocabulary are more important than grammatical correctness (if mistakes do not interfere with communication).

7. Reading training is considered one of the main areas of CLIL.

Integrated learning has many language and meaningful advantages. One of them is familiarity of students not only with the language, but also with a wide cultural context. The students should be prepared for internationalization, and CLIL helps them with this. 
Many students are focused on moving abroad after graduation, so they should be free to navigate in a foreign environment and have the necessary professional competence in another language. They automatically get this after studying on the CLIL methodology, and thereby provide themselves with a better professional future.

The international approach to learning provides a variety of methods and styles of the process itself, which also positively affects the pedagogical aspect.

Instead of focusing on improving one of the four language skills (speaking, writing, listening and reading) of students, CLIL technique causes each of them to develop simultaneously.

The implementation of CLIL methodology in the process of foreign language education requires to take into account the following principles of studying the subject and language:

1. Multichannel focus: all subjects undergo an integration, topics correlate with each other, the learning process is analyzed. The analysis helps to determine where the student is at the appropriate stage and to establish the further direction of studying. It is important to help students find the most relevant learning styles and develop them, as well as to provide with such necessary language skills in order to effectively continue their non-native language learning.

2. The learning medium is safe and supportive: friendly relations and co-learning are maintained. Language errors in the process of speaking are not corrected: the task of the teacher is to formulate them in the correct form or to paraphrase them. The teacher understands the level of knowledge of each student, monitors the material passed and plans classes based on this information.

3. All needs and interests of the student are taken into account. The learning process itself integrates into everyday life and other subjects, helping students create associative connections for more productive learning. Only relevant material from the mass media and other sources is used.

4. Students speak more than a teacher. CLIL involves active learning language learning and mastering the subject is achieved through discussions. The teacher creates situations for polylogue and directs students. In this way, critical thinking skills develop. The mission of the discussions can 
be different: to get an actual answer to the question, to stimulate thinking and talent for analysis, to motivate the search for non-standard solutions. The more active a student thinks, the more he remembers.

5. New knowledge and experience of the student are based on previous skills, knowledge and experience, his interests and settings. The student learns to accept challenges, and the specialist helps to cope with them. The teacher supports the development of creative and critical thinking in a foreign language.

6. Teacher cooperation: planning of subjects, language lessons and common topics requires good relationships and synergy between subject teachers and language teachers. Management, various departments, employers are involved in the planning and organization process. The quality of synergy is analyzed and evaluated. Teachers exchange feedback all the time and receive it from students [5].

CLIL methodology assumes that the teacher is not the only source of information for students. Authentic materials are used: texts and tasks are real and relevant, and language learning is associated with life situations and goals.

The implementation of the CLIL methodology in European universities is largely related to the understanding of English as a global language within the framework of internationalization of the higher education entire field. The experience of teaching a subject in a second language other than the native language (in most cases - in English) can be classified according to three models of integrated learning proposed by Coyle D. [6].

Model C1: Multilingual teaching. Integrated learning involves the use of more than one language in different years of study and in teaching different subjects. Completing training according to this model, the student acquires professional knowledge in several languages. The model is considered prestigious: it is designed to attract the most highly motivated students from different countries.

Model C2: Additional integrated subject and language teaching. The language is taught in parallel with other subjects, but at the same time the emphasis is on the development of knowledge and skills that are necessary for the professional use of language and support of higher-order mental processes. Language teaching is associated with special spheres; the teachers are part of structural departments in different specialties. 
After learning according to this model, students acquire the ability to use the language specifically for work in their specialty.

Model C3: Subject courses with the inclusion of language support. Training programs are worked out in terms of development and acquisition of language skills. Training is carried out both by subject teachers and by language specialists. Even the student with a low level of language knowledge can feel comfortable because he receives full support throughout the learning process. This method makes it possible to master both the subject and the language of its teaching. The model is suitable for teaching students with different language and cultural backgrounds.

Model C1 is implemented only in universities of a certain specialization (for example, business), and models $\mathrm{C} 2$ and $\mathrm{C} 3$ are the most common.

If we talk about the development of CLIL in Ukraine, it should be noted that now the implementation of this technique is episodic. Its implementation is carried out partially within the framework of individual educational establishments.

\section{Cases of implementation of CLIL methodology in Europe}

Today, the use of CLIL methodology is most common in Western Europe (Belgium, France, Germany, etc.). In addition, the above mentioned methodology is used in Spain, Estonia, Russia, Poland, Latvia, Italy, Finland, the Czech Republic and other countries of the world.

The peculiarities of implementing CLIL methodology in different countries depend on the selected model. Thus, there are three CLIL models: soft (language-led), hard (subject-led), partial immersion. The first model is aimed at linguistic features of the special context, the second means that $50 \%$ of the curriculum subjects in the speciality are studied in a foreign language, and the third one occupies an intermediate position, and is used when some modules from the program in the speciality are studied in a foreign language [7].

Bilingual schools, in which comprehensive subjects are studied in a foreign language, exist in Hungary for a long time already. In Bulgaria, the use of the aforementioned methodology has been carried out for about 50 years and is still of interest to specialists working in this field. According to this methodology, bilingual schools in Bulgaria teach subjects such as History, Geography, Philosophy, and to implement the educational process English, German, French, Spanish and other languages are used [7]. 
Implementation of CLIL methodology in the practice of specialized schools of former-Soviet countries, in particular Ukraine, has not found development and distribution in universities, unlike other countries. Although in our opinion, the integration processes and the focus of Ukraine to improve the level of foreign language proficiency make it necessary to return to the issue of implementing CLIL methodology in schools and universities of the country [2, p. 240].

The use of CLIL methodology in different countries made it possible to determine its advantages, as well as certain problems of its implementation in the educational process.

Among the analyzed positive aspects of the above mentioned methodology should be noted an increase of motivation for learning a foreign language, purposefulness to mastering a foreign language to solve specific communicative problems, prioritizing the achievement of skills for communication in a foreign language in a professional context, immersion in an artificially created language medium, the assimilation of specific terms, certain language structures and the expansion of vocabulary.

Most CLIL researchers note many difficulties in its implementation: insufficient amount of permanent teaching resources, inadequate training and lack of professional development, difficulties in the selection of materials for teaching, the need to overcome parental resistance to the above mentioned approach [11, p. 58].

After successful experiments on the implementation of CLIL methodology, serious discussions were caused in some countries about the further dissemination of the use of this methodology. For example, in France, after the success of 1992, the question arose about the need to expand the methodology, or use it only with a separate group of highly motivated students. Also significant questions for discussion arose in Belgium (Flemish region), Lithuania, Sweden, Iceland and Norway.

Thus, in these five countries, the debate concerns teaching, namely whether the use of CLIL methodology, specifically intensive learning of a foreign language, can cause harm to a native language. In Sweden, they are concerned about the problem of a possible decrease in the level of subject knowledge that is taught in a foreign language. In the Netherlands, there is an interest in the possibility of introducing CLIL methodology into incomplete secondary professional education and primary school. 
However, the main challenge is the lack of qualified teachers. In Bulgaria, the authorities are dealing with pressure from teachers demanding higher salaries and reduced workload. All other cases discussed relate to the issues, which subjects should be taught according to CLIL methodology and how much time should be given to it in the curriculum [6, p. 54].

Despite the fact that CLIL methodology is introduced in different countries taking into account the specifics of each of them, the range of problems can be clearly summarized and reduced to the problems of human resources, legislative, material and financial aspects and those related to the educational process [6, p. 51].

However, we can also talk about the success in implementing CLIL methodology in some countries. Thus, in Bulgaria, a project was supported, the main purpose of which was to create CLIL courses to improve the skills of subject teachers, as well as the development of educational materials for teachers and students. Many universities have already held classes in a foreign language with teachers; consultations are provided in the preparation of educational materials.

Thus, the use of CLIL methodology corresponds to the functional approach to teaching a foreign language and allows achieving even greater efficiency in its mastery by creating an artificial language medium, the conceptual context and contributing to increasing the motivation of those who study. Despite the common problems arising in the process of approbation of CLIL methodology, the experience of Bulgaria, Russia and other countries proves the effectiveness and possibility of using CLIL methodology. The prospect of further research is considered to be the study of the possibility of CLIL methodology implementing in higher educational establishments of Ukraine.

\section{Implementation of CLIL in Ukraine}

The need to improve the level of professional English of students contributed to the search of new effective methods of its teaching.

CLIL methodology is quite successfully used in practice in the European Union, but the question of the introduction of this methodology in higher educational establishments of Ukraine still remains open. The application of integrated learning involves the dual nature of the use of language: language as a goal, and language as a means. The analysis of the methodology in the 
context of the chosen discipline, which is perceived as a practical course of learning a foreign language, is especially important for the research. The main advantage of CLIL involvement is the accomplishment of crosscultural consciousness, the development and improvement of language competencies and increasing the motivation of students. The development of students' language competence could move to a qualitatively new level if the application of the submitted methodology is studied at practical classes.

When developing a course of study on the basis of this methodology, it is necessary to take into account 4 «C» methods of CLIL: content, communication, cognition (mental abilities), culture (cultural knowledge). Also, when determining the main principles of CLIL, the following five aspects are distinguished, which are implemented differently depending on the age of the student, the socio-linguistic environment and the level of immersion in CLIL: cultural, social, linguistic, subject and educational aspects.

To implement the CLIL methodology in the curriculum, it is necessary to carefully study the characteristics and features of the types of bilingual teaching.

The first type is «merging», that is, teaching the second state language. At the same time, teachers are native speakers of this language and have the appropriate qualifications. The theory and practice of bilingual education arose in Canada in the 1970s, when students were taught French in parallel.

The second type - «subordination»-is associated with the linguistic and cultural integration of migrants (linguistic minority). In this case, students learn the language of majority to successfully internalize the curriculum, as well as to use the language in everyday life. Consequently, competencies in language mastering are implemented through learning. This practice is common for teaching migrant children in many European countries.

The third type is the method of subject-language integration, which is a form of bilingual education and reflects certain relationships between the subject, student and language. In this case, the integration of the language can be defined as an educational approach, in the use of which a foreign language is used as a means of teaching a number of educational subjects to an ordinary cohorts of students.

The main objectives of CLIL methodology are the following:

- development of intercultural communication skills; 
- studying professional terminology in the target language;

- studying thematic disciplines from different points of view;

- improving the overall competencies of the language being studied;

- development of oral speech skills;

- diversity of methods and forms of classroom classes;

- increasing students' motivation.

One of the most important advantages of CLIL methodology can be determined as increasing students' motivation to learn a foreign language. Skills of communication in a foreign language in a professional context become a priority. Students have the opportunity to better cognize and understand the culture of the language being studied, which leads to the formation of sociocultural competence. Full immersion in the natural language medium allows students to learn specific terms, certain language structures, thus preparing them for further study and use of the knowledge and skills gained.

Despite the significant number of advantages of implementing CLIL methodology in higher educational establishments of Ukraine, there are also certain difficulties in the implementation of these innovations. After all, teachers should have the language competence and methodology of teaching foreign languages together with the method of teaching academic subjects.

To implement CLIL innovative methodology, teachers must obtain the following skills and competencies as:

- knowledge of psychological aspects of bilingual teaching;

- language skills in the field of the discipline taught;

- knowledge of a large number of methods of teaching discipline and foreign language;

- the ability to teach a discipline in a foreign language; alacrity to continuous professional development.

That is, to implement such methodology in higher educational establishments of Ukraine, highly qualified teachers who are able to lecture and conduct practical, seminar or laboratory classes in two languages are required.

The next problem in the implementation of CLIL methodology can be called the development of new training programs and the preparation of educational material. In addition to proficiency in a foreign language, 
the methodology of content and language integrated learning requires an innovative approach to conducting classes, that is, the use of various forms of material presentation, the organization of work that will be directed to the individual and creative activities of students. Thus, teachers who use CLIL methodology must have specific professional competencies to effectively implement this methodology.

Among other disadvantages of implementing the CLIL methodology in higher educational establishments of Ukraine, we can highlight the following ones:

- lack of highly qualified teachers for the implementation of CLIL methodology;

- difficulty in training the necessary personnel; problems associated with the development of new curricula, selection of educational materials, etc.;

- lack of funds for Ukrainian teachers to complete study placement abroad and to invite teachers from Europe to Ukraine.

\section{Using CLIL in studying the Topic of Political Systems}

During 4th year of study, students learn the topic «Political systems in the UK and the USA», which is considered one of the most difficult for learning, because in order to study all the subtleties of the political systems of English-speaking countries in English, students must understand the basic concepts in their native language, that is, Ukrainian. In the practical lesson, students are offered not only the text describing the political systems of the countries submitted, but also the tasks for it and video material. Let us give an example of lexical units that students should learn in a practical lesson on the topic «Political systems in the UK and the USA»: in the domain of, to repeal, to reinstate, figurehead, retinue, constituency, allegiance, rationale, raisond'etre, reiteration, spin doctor, election manifesto, parliamentary majority, valid constitution, parliamentary alliances, amendments to the constitution, dissolve parliament, political make-up, to climb on the bandwagon, election canvassing, vote-catcher, parliamentary faction, a back-bencher [1, p. 110], students must first learn and understand their native language, so an explanation in practical lessons is also given in their native language.

In order to understand the complexity of texts and tasks, as well as to assess the amount of knowledge and skills gained by students in the process 
of working with the text and performing tasks, we give an excerpt from the text that provides a description of the USA political parties:

"The United States puts no legal limits on the number of political parties that may operate. Thus, it is theoretically a multi-party system, although political parties are not mentioned in the U.S. Constitution. Parties are, however, regulated by the constitutions of the individual states, which organize elections to both local and federal offices. In practice, since the mid-1800s, the country has been limited to a two-party system with occasional inroads made by third parties. This is largely a consequence of the first-past-the-post election system and restrictive ballot access laws imposed on the other political parties, as well as the leadership rules in Congress.

There have been many political parties other than the two dominant ones (the Republican Party and the Democratic Party), but most third parties are generally considered to be of only minor and short-lived political significance. The two main parties hold glamorous, almost circuslike conventions to choose candidates for Presidential elections.

US political parties are grouped into four sections. The first section is called "Current major parties", and it lists the two dominant parties mentioned above. The second section is called "Current third parties" and it consists of those parties that have achieved (or, in the lead-up to an election, are reasonably expected to achieve) ballot status for their respective candidates for President of the United States in states with enough electoral votes to have a theoretical chance of winning. The third section is called "Current minor and regional parties that have endorsed candidates" and consists of all the other currently active parties which have candidates. The last section, "Defunct political parties," is for political parties that no longer exist.

An alternate means for categorizing U.S. political parties, historically and currently, is to apply the Federal Election Commission's definition of "national committees" retroactively back in time to the beginning of the U.S.» [1, c. 116].

After working with the text and studying new lexical units, the reinforcement of the learned material is supported by the video material in which a resident of the United States, a native speaker, brings to the recipients information about the functioning of political parties in America. 
Also, on the example of the 2016 presidential election in the United States, when Donald Trump won, America's electoral system was examined, because it is radically different from the electoral system of Ukraine, and therefore causes some difficulties in studying. The study of such material forms students' intercultural competence.

Having gained a certain amount of knowledge and skills in the process of studying the topic «Political systems in the UK and the USA», students should receive and master the skills of translating texts from Ukrainian to English on the topic presented. So, let's give an example of a text that students can freely translate after studying the above topic (the extract is taken from the students' textbook in Ukrainian):

«...Однак $\epsilon$ декілька основних принципів, які можна знайти на всіх рівнях американського урядування. Один з них “одна людина - один голос" свідчить про те, щзо законодавиі обираються від географічних районів вибориями напряму. Відповідно до изього принципу, всі виборчі райони повинні мати приблизно однакову кількість мешканців.

Інший фундаментальний принщип американського урядування полягає у тому, що завдяки системі контролю та рівноваги компроміс у політиці необхідність, а не вибір. Наприклад, Палата представників контролює витрати та фінанси, отюе, президент повинен отримати згоду на свої пропозиції та програми. Він не може оголосити війну без згоди Конгресу. У закордонних справах він також дуже обмежений. Кожний договір повинний спочатку бути схвалений Сенатом. Якщо немає згоди, то й немає угоди. Правило говорить, щэо "президент пропонує, Але Конгрес наказує”. Таким чином, те, щзо президент хоче зробити, відрізняється від того, щчо президент має можливість зробити.

....Майже всі вибори у США базуються на приничипі "переможецьь отримує все”: кандидат, який набрав найбільшу кількість голосів у конгресовому районі, є переможием.

Конгрес приймає закони, кожна палата Конгресу має повноваження вносити законопроекти. Кожна палата також може голосувати проти законопроектів іншої палати. Оскільки законопроект стає законом, якщз його приймають обидві палати, то їм необхідно досягти компромісу.

Конгрес приймає рімення щзодо податків та грошових витрат. Крім того, він регулюе торгівлю між штатами та з іноземними 
країнами. Він також встановлюе правила надання громадянства іноземиям» [1, с. 118].

To study the topic, students considered not only the information provided, but also turned to many English-language sources from which they received information about the political systems of English-speaking countries, as well as learned the practice of holding presidential elections, thereby raising cross cultural consciousness.

Based on the proposed texts and additional materials, the students:

- gained intercultural communication skills;

- studied professional terminology in English;

- improved oral speech skills (monologic speech and oral translation);

- increased cross cultural consciousness.

So, after a practical English course on «Political systems in the UK and the USA», we received the following results:

- in the professional field (English language learning) - vocabulary in the field of political systems significantly expanded, oral speech and translation skills in the topic improved;

- in the interdisciplinary sphere - got an idea of the political systems of English-speaking countries, the structure of political parties and the holding of presidential elections.

The conclusion can be made that in order to implement such a methodology in higher educational institutions of Ukraine, highly qualified teachers are needed who are able to lecture and conduct practical, seminar or laboratory classes in two languages. The teachers who use CLIL methodology must have specific professional competencies to effectively implement this methodology. But it is in the preparation of the necessary personnel, the development of new curricula and the selection of materials that are the main difficulties in the implementation of content and language integrated learning in higher educational establishments of Ukraine.

CLIL methodology is becoming increasingly popular in teaching a foreign language of professional communication in Ukrainian higher education establishments, which is due to a number of factors. Firstly, modern higher education aims to fulfill the order of society, that is, the training of the specialists who not only obtain the speciality, but also professional English. Secondly, English is increasingly becoming the language of teaching postgraduate education programs. Thirdly, the knowledge of professional 
communication skills in English allows the applicant of higher education or a graduate of a higher educational establishment to conduct research in foreign universities, participate in international research groups and publish the results of the research in international scientific journals. Thus, globalization in the modern world, European integration of Ukraine, the development of the latest methods of teaching a foreign language accelerate the introduction of various teaching methods to improve the quality of education in higher educational establishments of Ukraine.

The analysis shows that the issue of the introduction of content and language integrated learning today occupies one of the leading places in the research of both Ukrainian and foreign scientists. The most common and promising methods of teaching foreign languages adopted in the European Union are CLIL (Content and Language Integrated Learning) and CALL (Computer Assisted Language Learning), as the analysis of recent publications in this field shows $[3 ; 5 ; 8]$. Such Ukrainian scientists as S. Bobil, Y. Rudnik, Y. Sobol and many others studied various aspects of content and language integrated learning. Among the foreign scientists who considered this issue can be distinguished such researchers as M. Allen, D. Laddol, L. Collins, D. Marsh, etc. To date, a large number of scientific publications justify the need to implement CLIL in higher educational establishments of Ukraine $[3 ; 6 ; 7 ; 9]$.

Many European countries quite successfully use CLIL methodology in practice, but the question of the introduction of this methodology in higher educational establishments of Ukraine, in particular in practical English courses, remains open. After all, the main advantage of CLIL involvement is the education of cross cultural consciousness, the development and improvement of language competencies and increasing the motivation of students. The development of the language competence of students could move to a qualitatively new level if the application of this methodology is studied at specifically practical classes.

\section{Conclusions}

Today, professional success is caused not only by specific skills, but largely depends on the ability to communicate freely with specialists from other countries. Modern society is developing rapidly, and it has serious processes of modernization of education. This demands the development and 
implementation of innovative teaching methods that would meet the urgent need for internationalization. The effectiveness of CLIL methodology is ensured by conducting lessons in modern forms of interaction between the teacher and the student, with the use of innovative educational technologies, and allows students to simultaneously study both the language and the professional subject, with a parallel study of all important terminology and language features of the speciality.

As a conclusion, it is necessary to highlight two main advantages of using CLIL methodology in higher educational establishments.

The first advantage is that in the case of integrated learning, the attention of both the students and the teacher is initially balanced between subject content and language with the priority of content (language learning through the content of the speciality in the FL course). Then the attention is less and less focused on the language, and more and more on subject content (foreign-language immersion in courses of special disciplines). As a result, the skills and abilities of professional communication in foreign language are mastered, formed and developed mostly reflexively, as a spinoff of the extralinguistic activity, for which the language is actually learned. This creates much better conditions for the formation and development of speech skills, because such formation and development become quite natural processes.

The reason is that speech activities, or speech communication, are always a means of performing other activities [3]. If so, then, of course, the mastery of foreign language communication will be most effective only when it acts in this natural role - as a means by which other activities are carried out. The use of language as a means of extralinguistic activity, when the language itself can be mastered only as a spin-off of this activity, initiates the mechanisms of reflexive memorizing and even imprinting, which makes the mastering of language material and the process of learning language and speech in general rather easy, and also significantly increases the effectiveness of this process [5]. The second advantage is that in integrated learning it is virtually impossible to divide the teaching of language and teaching of the future speciality. As a result, FL is transformed into almost professional discipline with all the positive consequences that arise from such transformation. The conclusion based on the research in this article may be: to emphasize the urgent need to develop all aspects, forms 
and modifications of foreign language integrated learning for professional communication in non-language higher establishments of Ukraine with experimental and purely practical approbation of the developed methods. This is the main prospect of further research in the field of optimization and intensification of teaching a foreign language in the mentioned above higher educational establishments.

The introduction of CLIL methodology in Ukraine will be an indisputable step forward on the part of higher educational establishments - this will not only contribute to improving the level of students' qualification, but also will ensure competitiveness of the establishment by increasing the closeness of integration with foreign partners. But it should be noted that the introduction of the methodology into the educational medium of the university requires careful planning, organization and monitoring, as well as regular acceptance of feedback and its analysis.

\section{References:}

1. Vozna M. O., Haponiv A., Antoniuk N. M., Khomenko N. S., Perminova A.V./ za zah. red. prof. Karabana V.I. (2008) Anhliiska mova. IV kurs [English language the $4^{\text {th }}$ course]. Vinnytsia: Nova Knyha. (in Ukrainian)

2. Kochenkova O.M. (2012) Vozmozhnosti profilizaczii prepodavaniya inostrannykh yazykov s pomoshhyu primeneniya elementov metodiki CLIL (integrirovanie prepodavaniya inostrannogo yazyka i drugikh uchebnykh discziplin) [Possibilities of profile specificity of foreign languages teaching with the use of the elements of the CLIL method (integration of teaching a foreign language and other educational disciplines)]. Retrieved from: http://kochenkova.ru/publ/ vozmozhnosti_profilizacii_prepodavanija_inostrannykh_jazykov_s_pomoshhju_primenenija_ehlementov_metodiki_clil_integrirovanie_prepodavanija_inostrann/1-1-0-1

3. Movchan L.H. (2011) Vykorystannia dosvidu Shvetsii u vitchyznianii praktytsi navchannia inozemnykh mov [Using Swedish experience in foreign language teaching]. Humanizatsiia navchalno-vykhovnoho protsesu, vol. 7, pp. 214-220.

4. Necheporenko M.A. (2017) Intehratyvnyi resurs inozemnoi movy v konteksti problemy profesiino-osobystisnoho samorozvytku maibutnoho uchytelia [Integrative foreign language resource in the context of professional and personal self-development problem of the future teacher]. Science and Education a New Dimension. Pedagogy and Psychology, vol. 5(57), no. 129, pp. 25-28.

5. Tarnopolskyi O.B. (2011) Navchannia cherez zmist, zmistovno-movna intehratsiia ta inshomovne zanurennia u vykladanni inozemnykh mov dlia profesiinykh tsilei u nemovnykh vyshakh [Content-based learning, content-language integration and foreign language immersion in teaching foreign languages for professional purposes in non-language universities]. Inozemni movy, vol. 3, no. 67, pp. 23-27. 
6. Coyle D., Hood P., and D. Marsh (2010) Content and Language Integrated Learning. Cambridge, UK: Cambridge University Press. Retrieved from: https://d1wqtxts1xzle7.cloudfront.net/33938622/slrcoyle_CLIL_motivating_ teachers_and_learners.pdf

7. European Commission - ICF Improving the effectiveness of language learning: CLIL and computer assisted language learning. Retrieved from: http://ec.europa.eu/ languages/library/studies/clil-call_en.pdf

8. Ewa M. Golonka, Anita R. Bowlers, Victor M. Frank, Dorna L. Richardson and Suzanne Freynik (2012) Technologies for foreign language learning: a review of technology types and their effectiveness. Computer Assisted Language Learning. Retrieved from: http://www.sinocall.org/pdf/Technologies_for foreign-language.pdf

9. Marsh David, Peeter Mehisto, Dieter Wolff, Maria Jesus Frigols Martin (2012) European Framework for CLIL: Teacher Education. Retrieved from: http://encuentrojournal.org/textos/9.\%20CLIL-Framework.pdf

10. Marsh David (2002) The relevance and potential of content and language integrated learning (CLIL) for achieving $\mathrm{MT}+2$ in Europe. Retrieved from: http://userpage.fu-berlin.de/elc/bulletin/9/en/marsh.html

11. Ruiz de Zarobe, Y.R. (2013) CLIL Implementation: from policy makers to individual initiatives. International Journal of Bilingual Education and Bilingualism, 16:3: 231-243. 